\title{
TIGA CARA MENENTUKAN NAMA WUKU DALAM PAWUKON SAKA
}

\author{
Agung Prabowo \\ Jurusan Matematika, Fakultas Matematika dan Ilmu Pengetahuan Alam, \\ Universitas Jenderal Soedirman \\ Jl. Dr. Soeparno No. 61 Karangwangkal Purwokerto, Jawa Tengah \\ e-mail: agung.prabowo@unsoed.ac.id ; agung_nghp@yahoo.com
}

\author{
Sugiyanto \\ SMA Negeri 1 Kebumen \\ J1. Mayjen Sutoyo No. 7 Kebumen, Jawa Tengah \\ e-mail: giantogm@gmail.com \\ Indar Tri Wahyuni \\ SMA Negeri 2 Kebumen \\ Jl. Cincin Kota No. 8 Kebumen, Jawa Tengah \\ e-mail: indartw@gmail.com
}

\begin{abstract}
This article discusses Pawukon Saka which is a mathematical calendar.This article explains mathematical knowledge required to create Pawukon Saka and particularly called as Javanese Mathematics. The Pawukon Saka Calendar obtained is then used to check some calendars sculpted on various epigraphs using The Chinese Remainder Problem. There are some mistakes in the names of wuku sculpted on some epigraphs after checking.
\end{abstract}

Keywords: Javanese Mathematics, Pawukon Saka, The Chinese Remainder Problem

\begin{abstract}
Abstrak. Tulisan ini membahas mengenai Pawukon Saka yang merupakan suatu kalendar matematika. Artikel ini memaparkan pengetahuan matematika/aritmatika yang diperlukan untuk penciptaan Pawukon Saka dan secara khusus disebut sebagai Matematika Jawa. Kalender Pawukon Saka yang diperoleh digunakan untuk menguji penanggalan yang terpahat pada berbagai prasasti, dengan menggunakan bantuan solusi dari Masalah Sisa China (The Chinese Remainder Problem). Hasilnya, terdapat kekeliruan nama wuku yang terpahat pada beberapa prasasti.
\end{abstract}

Kata kunci: Matematika Jawa, Pawukon Saka, The Chinese Remainder Problem Mathematical Subject Classification 2010: 11A07

\section{PENDAHULUAN}

Pawukon Saka adalah jenis pawukon yang dipadukan dalam Kalender Saka. Jenis pawukon lainnya adalah Pawukon Jawa dan Pawukon Bali. Salah satu contoh penggunaan Pawukon Saka adalah pada Prasasti Sang Hyang Tapak (Cicatih/Jaya Bupati) yang ditemukan di Sukabumi, Jawa Barat dan berangka 
tahun 952 Saka (1030 Masehi). Saat itu, masyarakat Jawa telah mengembangkan pengetahuan matematika (sebut sebagai Matematika Jawa) yang digunakan untuk menciptakan Pawukon Saka.

Pawukon Saka merupakan mathematical calendar yang dibangun oleh tiga buah wewaran (pancawara, sadwara dan saptawara) serta tiga puluh buah wuku. Pawukon Saka dimulai pada saptawara Radite (Minggu) pancawara Paing, sadwara Tungle, wuku Sinta (Prabowo, 2014). Umur setahun (sekali siklus) Pawukon Saka adalah 210 hari yang disebut segrombol atau sedhapur (Prabowo, 2014).

Penggunaan Pawukon Saka pertama kali ditemukan pada prasasti-prasasti dari Mataram Kuno, kemudian menyebar ke Bali, Jawa Barat, Sumatera Barat dan lain-lain. Prasasti-prasasti yang berasal dari luar Jawa (dalam artikel ini Jawa adalah wilayah yang saat ini meliputi propinsi Jawa Tengah, Yogyakarta dan Jawa Timur) dan memahatkan adanya unsur-unsur Pawukon Saka dapatlah dipastikan mempunyai kaitan dengan Mataram Kuno. Sekarang ini, Pawukon Saka dikembangkan menjadi Pawukon Jawa dan Pawukon Bali. Tabel 1 menyarikan karakteristik dari Pawukon Saka.

Tabel 1 Karakteristik Pawukon Saka

\begin{tabular}{|l|l|}
\hline \multicolumn{1}{|c|}{ Karakteristik } & \multicolumn{1}{c|}{ Pawukon Saka } \\
\hline Unsur Pembangun & Pancawara, Sadwara, Saptawara, dan wuku \\
\hline Umur & 210 hari \\
\hline Hari Pertama & Radite-Paing, Tungle, wuku Sinta \\
\hline Hari Terakhir & Saniscara-Umanis, Mawulu, wuku Watugunung \\
\hline Penggunaan & Mataram Kuno - Mataram Islam (732 - 1633 M) \\
\hline Jenis & Mathematical calendar \\
\hline
\end{tabular}

Mengacu latar belakang, dimajukan rumusan masalah seperti apakah model matematika untuk menentukan nama wuku dan menguji kebenaran nama $w u k u$ pada prasasti-prasasti nunsatara untuk titik waktu tertentu pada kalender Pawukon Saka, sehingga tujuan penulisan artikel ini adalah membangun model matematika 
untuk menentukan nama $w u k u$ dan menguji kebenaran nama wuku pada prasastiprasasti nunsatara untuk titik waktu tertentu pada kalender Saka.

Model matematika yang dihasilkan dapat digunakan oleh seluruh khalayak untuk menentukan nama $w u k u$ serta menguji kebenaran nama $w u k u$ pada data-data prasasti, dengan menggunakan bantuan solusi dari Masalah Sisa China (The Chinese Remainder Problem). Sebagai contoh, Prasasti Cicatih (Sang Hyang Tapak atau Jaya Bupati) memahatkan nama wuku Tambir, padahal seharusnya Medangkungan.

\section{METODE PENELITIAN}

Penelitian dan hasil yang dituangkan dalam artikel ini diselesaikan dengan metodologi penelitian berupa kajian pustaka dan kajian data-data prasasti dengan mengambil sumber penelitian berupa prasasti-prasasti tertua yang dikeluarkan oleh Kerajaan Mataram Kuno dan kerajaan-kerajaan di Bali, Jawa Barat dan Sumatera Barat. Penggunaan prasasti didasarkan pada posisi prasasti sebagai sumber tertulis yang tertua. Prasasti-prasasti yang digunakan dalam penelitian ini dapat dilihat pada tabel 2 dan berupa prasasti yang dipahat pada batu (upala praasasti) dan logam (tripta praasasti).

\section{HASIL PENELITIAN DAN PEMBAHASAN}

Pawukon Saka dibangun oleh penguasa Mataram Kuno yang mendiami Jawa Tengah. Disebut Pawukon Saka sebab pawukon tersebut dipadukan dalam Kalender Saka yang masih digunakan hingga Mataram Islam.

Pawukon Saka dibangun secara matematik, dengan menggunakan Matematika Jawa. Oleh karena itu, dalam artikel akan ini dibahas pengetahuanpengetahuan Matematika Jawa yang dipastikan sudah dimiliki manusia Jawa pada saat penciptaan dan penggunaan Pawukon Saka.

Umur setahun Kalender Masehi adalah 365/366 hari dan pembuatannya berdasarkan peredaran matahari selama setahun sehingga Masehi disebut solar calendar. Penentuan perjalalan waktu dalam setiap bulannya sudah ditetapkan dan 
tidak akan berubah sehingga Masehi merupakan mathematical calendar (Prabowo dan Sidi, 2012).

Kalender Hijriah dibangun oleh siklus 354/355 hari berdasarkan peredaran bulan selama setahun sehingga Hijriah disebut lunar calendar. Penentuan perjalalan waktu dalam setiap bulannya tergantung pada perubahan bentuk bulan sehingga Hijriah merupakan astronomical calendar (Prabowo dan Sidi, 2012).

Kalender Jawa (Kalender Mataraman/Sultan Agungan) juga merupakan lunar calendar sebab setahun umurnya 354/355 hari. Penyusunan Kalender Jawa berdasarkan perhitungan/aturan matematis sehingga disebut mathematical calendar (Prabowo dan Sidi, 2012).

Masyrakat Jawa juga pernah menggunakan kalender Saka yang merupakan solar calendar tetapi perhitungan jumlah hari tiap bulannya mengikuti perubahan bentuk bulan. Akibatnya, Saka merupakan luni-solar calendar. Setahun kalender Saka umurnya 354 hari dan akan mencapai 383/384 hari pada tahun kabisat. Pengertian tahun kabisat pada kalender Saka adalah setahun berjumlah 13 bulan. Hal ini berbeda dengan pengertian tahun kabisat pada kalender Masehi (tambah 1 hari pada Februari), Hijriah (tambah 1 hari pada bulan Dzulhijjah) dan Jawa (tambah 1 hari pada bulan Besar).

Saat ini, kalender Saka masih terus digunakan di Bali. Di Jawa hanya digunakan oleh pemeluk Hindu dan Budha. Artikel ini mempertahankan penggunaan angka tahun pada Kalender Saka (S). Konversi menjadi Masehi (M) dengan menambah 78 pada angka tahun Saka (Prabowo dan Sidi, 2014).

Bagaimana dengan Pawukon Saka? Apakah Pawukon Saka merupakan solar calender, lunar calendar, luni-solar calendar, astronomical calendar atau mathematical calendar?

\section{Wewaran dan Jenis-Jenisnya}

Kata wewaran berasal dari bahasa Jawa Kuno, 'wara' yang berarti hari dengan imbuhan we + an sehingga menjadi wewaraan, berubah menjadi wewaran. Istilah wewaran berarti kelompok hari atau pengelompokan hari. Penggunaan wewaran saptawara telah dimulai tahun 654 S, terpahat pada Prasasti 
Canggal. Penggunaan dua wewaran berikutnya (pancawara dan sadwara) dimulai sejak 714 S pada Prasasti Manjusrigraha (tabel 2). Prasasti-prasasti yang menggunakan Kalender Saka hingga runtuhnya Majapahit hanya memahatkan tiga jenis wewaran (pancawara, sadwara, dan saptawara).

Ketika Kalender Saka digunakan, nama-nama pancawara adalah Pahing, Pon, Wagai, Kaliwuan dan Umanis/Manis. Penulisan pada prasasti terkadang menggunakan singkatan $\mathrm{Pa}, \mathrm{Po}, \mathrm{Wa}, \mathrm{Ka}$ dan $\mathrm{U}$ atau Ma. Nama-nama hari sadwara adalah Tungle, Aryang, Wurukung, Uwas, Paningron dan Mawulu. Dalam prasasti, terkadang ditulis $t u$ atau tung = tunglai, $h a=$ hariyang, $w u=$ wurukung, $p a=$ paniruan, $w a=$ was, dan $m a=$ mawulu. Nama-nama hari saptawara dalam prasasti ditulis dengan singkatan (Damais, 1951 dan de Casparis, 1978 dalam Andreanto, 2008) $r a$ atau $a=$ Raditya atau Aditya (Minggu), $s o=$ Soma $($ Senin $)$, ang = Anggara $($ Selasa $), b u=$ Budha $($ Rabu $), w r=$ Wrhaspati (Kamis), su = Sukra (Jumat) dan sa = Saniscara (Sabtu). Contoh-contoh prasasti yang memahatkan wewaran dan wuku diberikan pada tabel 2.

Tabel 2 Nama-nama wewaran dan wuku yang terpahat dalam berbagai prasasti

\begin{tabular}{|c|c|c|c|c|c|c|}
\hline \multirow[t]{2}{*}{ No } & \multirow[t]{2}{*}{ Nama Prasasti } & \multicolumn{3}{|c|}{ Wara } & \multirow[t]{2}{*}{ Wuku } & \multirow{2}{*}{$\begin{array}{l}\text { Tahun } \\
\text { (Saka) }\end{array}$} \\
\hline & & Sadwara & Pancawara & Saptawara & & \\
\hline \multicolumn{7}{|c|}{ Jawa Tengah, Jawa Timur dan Yogyakarta } \\
\hline 1 & Canggal & - & - & soma & - & $654 \mathrm{~S}$ \\
\hline 2 & Manjusrigraha & was & pon & sukra & - & $714 \mathrm{~S}$ \\
\hline 3 & Wantil & wurukung & wagai & wrehaspati & - & $778 \mathrm{~S}$ \\
\hline 4 & Wayuku & vurukum & pahim & sukra & - & $779 \mathrm{~S}$ \\
\hline 5 & Bulai & $w u ; p a$ & po; $k a$ & so; $b u$ & - & $782 \mathrm{~S}$ \\
\hline 6 & Tugu Upit I & wurukun & kaliwuan & soma & - & $788 \mathrm{~S}$ \\
\hline 7 & Poleng II & tunlai & pon & soma & - & $797 \mathrm{~S}$ \\
\hline 8 & Kapuhunan & $p a$ & $u$ & $s u$ & - & $800 \mathrm{~S}$ \\
\hline 9 & Ra Tawun & $t u$ & $w a$ & $s u$ & & $803 \mathrm{~S}$ \\
\hline 10 & Poh Dulur & tumlai & pon & soma & - & $812 \mathrm{~S}$ \\
\hline
\end{tabular}




\begin{tabular}{|c|c|c|c|c|c|c|}
\hline 11 & Kandangan & was & wagai & wŗhaspati & - & $828 \mathrm{~S}$ \\
\hline 12 & Mantyasih & $t u$ & $u$ & $s a$ & - & $829 \mathrm{~S}$ \\
\hline 13 & Kwak I & wurukum & umanis & soma & - & $905 \mathrm{~S}$ \\
\hline 14 & Pakis Wetan & $w a$ & $w a$ & $a \dot{m}$ & mahatal & $1188 \mathrm{~S}$ \\
\hline 15 & Kudadu & $h a$ & $u$ & $s a$ & $\begin{array}{l}\text { madàn } \\
\text { kan்an }\end{array}$ & $1216 \mathrm{~S}$ \\
\hline 16 & Sukamerta & tum & $k a$ & $c a$ & kuninan & $1218 \mathrm{~S}$ \\
\hline 17 & Tuhanaru & tun & $u$ & $a \dot{n}$ & krulwut & $1245 \mathrm{~S}$ \\
\hline 18 & Gajah Mada & $h a$ & po & $b u$ & tolu & $1273 \mathrm{~S}$ \\
\hline 19 & Pamintihan & $m a$ & $m a$ & su & lankir & $1395 \mathrm{~S}$ \\
\hline \multicolumn{7}{|c|}{ Bali } \\
\hline 20 & Pandak Badung & $w a$ & untuk & $w r$ & gumrg & $993 \mathrm{~S}$ \\
\hline \multicolumn{7}{|c|}{ Jawa Barat } \\
\hline 21 & Mandiwunga & haryang & pon & wrehaspati & - & - \\
\hline 22 & Candi Abang & $w u$ & $k a$ & $a \dot{m}$ & - & $794 \mathrm{~S}$ \\
\hline 23 & Cicatih & $h a$ & $k a$ & $r a$ & tambir & $952 \mathrm{~S}$ \\
\hline \multicolumn{7}{|c|}{ Sumatera Barat } \\
\hline 24 & Padang Roco & mawulu & wage & wrhas-pati & $\begin{array}{c}\text { Madang } \\
\text { kungan }\end{array}$ & $1208 \mathrm{~S}$ \\
\hline
\end{tabular}

\section{Wuku}

Pawukon merupakan hitungan waktu yang berlangsung selama 210 dan terbagi menjadi 30 kali siklus tujuh harian. Siklus tujuh harian ini disebut wuku. Meskipun umur setiap $w u k u$ tujuh hari dan pergantian $w u k u$ mengikuti selesainya siklus saptawara, wuku bukan mingguan. Oleh karena pergantian wuku setiap tujuh hari, maka banyaknya wuku adalah 30 buah.

Nama-nama $w u k u$ yang dipahatkan pada berbagai prasasti dengan nama $w u k u$ yang saat ini digunakan relatif tidak jauh berubah. Pada tabel 3, w adalah nomor urut wuku dan sisa $t$ menyatakan nama-nama hari setiap jenis wewaran. 
Sebagai contoh, $w=17$ berarti wuku Kuru Wlut dan $t=2$ berarti pon (pada pancawara), hariyang (pada sadwara) dan soma (pada saptawara).

Tabel 3 Nama-nama hari setiap jenis wewaran dan nama-nama wuku

\begin{tabular}{|c|c|c|c|}
\hline \multirow[t]{3}{*}{$\begin{array}{c}\text { Jenis } \\
\text { Wewaran }\end{array}$} & $\begin{array}{c}\text { Nama-Nama } \\
\text { Hari dalam } \\
\text { Prasasti } \\
654-1555 \mathrm{~S} \\
732-1633 \mathrm{M}\end{array}$ & \multicolumn{2}{|c|}{$\begin{array}{c}\text { Nama-nama Wuku dalam Prasasti } \\
952 \text { S - Kini } \\
1030 \text { M - Kini }\end{array}$} \\
\hline & $\begin{array}{c}\text { Sisa } \\
t\end{array}$ & \multicolumn{2}{|c|}{$\begin{array}{c}\text { Nomor Urut } W u k u \\
w\end{array}$} \\
\hline & (1) & \multicolumn{2}{|c|}{$(2)$} \\
\hline \multirow[t]{5}{*}{ Pancawara } & 1. Pahing & 1. Sinta & 16. Pahang \\
\hline & 2. Pon & 2. Landep & 17. Kuru Wlut \\
\hline & 3. Wagai & 3. Wukir & 18. Marakih \\
\hline & 4. Kaliwuan & 4. Krantil & 19. Tambir \\
\hline & 5. Umanis/Manis & 5. Tolu & 20. Madañkunan \\
\hline \multirow[t]{6}{*}{ Sadwara } & 1. Tunglai & 6. Gumbreg & 21. Maha Tāl \\
\hline & 2. Hariyang & 7. Wariganing Wariga & 22. Wuyai \\
\hline & 3. Wurukung & 8. Wariga & 23. Manahil \\
\hline & 4. Paniruan & 9. Julung & 24. Prang Bakat \\
\hline & 5. Was & 10. Julung Sungsang & 25. Bala (Muki) \\
\hline & 6. Mawulu & 11. Dunulan & 26. Wugu-Wugu \\
\hline \multirow[t]{7}{*}{ Saptawara } & 1. Raditya & 12. Kunin்an & 27. Wayang-Wayang \\
\hline & 2. Soma & 13. Laṅkir & 28. Kulawu \\
\hline & 3. Anggara & 14. Maḍasidha & 29. Dukut \\
\hline & 4. Budha & 15. Julung Pujut & 30. Watugunung \\
\hline & 5. Wrhaspati & & \\
\hline & 6. Sukra & & \\
\hline & 7. Saniscara & & \\
\hline
\end{tabular}

\section{Matematika Jawa dalam Pawukon Saka}

\section{Fungsi Tangga Naik dan Fungsi Tangga}

Fungsi Tangga Naik digunakan untuk menentukan bilangan bulat terkecil yang lebih besar dari atau sama dengan suatu bilangan. Sebagai contoh, bilangan bulat yang lebih besar dari atau sama dengan 15,01 adalah 16, 17, 18, ... Bilangan 
bulat terkecil yang lebih besar dari atau sama dengan 15,01 adalah 16. Demikian juga, bilangan bulat terkecil yang lebih besar dari atau sama dengan 25 adalah 25 .

\section{Definisi 1: Fungsi Tangga Naik dalam Matematika Jawa}

Jika $x$ suatu bilangan, maka fungsi tangga naik dari $x$ disimbolkan dengan $\langle\langle x\rangle\rangle$ adalah bilangan bulat terkecil yang lebih besar dari atau sama dengan $x$.

\section{Modulo Jawa}

Modulo Jawa merupakan salah satu pengetahuan dalam Matematika Jawa yang sedikit berbeda dengan konsep modulo dalam matematika. Modulo Jawa hanya bekerja pada bilangan asli. Akibatnya, sisa (disebut turah dalam Modulo Jawa) tidak pernah bernilai 0. Sebagai contoh, dalam modulo 5, sisa dari 24 adalah 4, berlaku dalam Modulo Jawa maupun matematika. Tetapi, sisa dari 25 adalah 5 dalam Modulo Jawa sedangkan dalam matematika sisanya 0. Perbedaan tersebut menuntut penggunaan simbol yang berbeda, mo $\delta$ (dalam Modulo Jawa) dan mod (dalam modulo matematika)

$$
\begin{aligned}
& 24(\bmod 5)=4 \quad 25(\bmod 5)=0 \quad \text { (Matematika) } \\
& 24(\operatorname{mo\delta } 5)=4 \quad 25(\operatorname{mo\delta } 5)=5 \quad \text { (Matematika Jawa) }
\end{aligned}
$$

Proses penentuan turah (sisa) dalam Modulo Jawa dilakukan dengan cara pengurangan berulang. Sesuai dengan konsep modulo dalam matematika dan Modulo Jawa, diperlihatkan adanya perbedaan proses pengurangan berulang:

\section{Matematika}

$24-5-5-5-5=4($ sisa 4$)$

$$
25-5-5-5-5-5=0(\text { sisa } 0)
$$

Matematika Jawa

$$
24-5-5-5-5=4(\text { sisa } 4) \quad 25-5-5-5-5=5(\text { sisa } 5)
$$

Dari ilustrasi-ilustrasi di atas, dapat dibuat definisi:

Definisi 2: Modulo dalam Matematika

$$
x(\bmod y)=s \text { didefinisikan sebagai } x=j y+s ;
$$




$$
\begin{aligned}
\text { dengan } s & =0,1, \ldots,(y-1),(s=\text { sisa }) \\
j & =0,1, \ldots
\end{aligned}
$$

\section{Definisi 3: Modulo dalam Matematika Jawa}

$$
\begin{gathered}
x(\operatorname{mo} \delta y)=t \text { didefinisikan sebagai } x=k y+t ; \\
\text { dengan } t=1,2, \ldots, y,(t=\text { turah }=\text { sisa }) \\
k=1,2, \ldots .
\end{gathered}
$$

Perhatikan bahwa tidak pernah ada turah (sisa) 0 dalam Modulo Jawa. Modulo Jawa juga baru bekerja pada saat siklus pertama dimulai $(k=1,2, \ldots)$. Akibatnya, $1(\operatorname{mo} \delta 5), 2(\operatorname{mo} \delta 5), 3(\operatorname{mo} \delta 5), 4(\operatorname{mo} \delta 5), 5(\operatorname{mo} \delta 5)$ tidak pernah ada (belum ada modulo) sebab siklus pertama belum terjadi. Juga, tidak akan ada

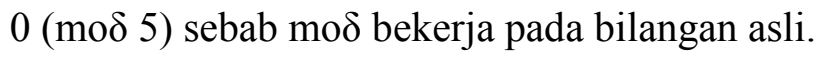

\section{Aturan Matematika Jawa dalam Pembuatan Pawukon Saka}

Pawukon Saka dibangun oleh tiga buah wewaran yaitu pancawara, sadwara dan saptawara serta 30 buah wuku. Pawukon Saka dimulai pada wuku Sinta, Radite-Paing, Tungle.

Dalam rentang waktu 210 hari, siklus pancawara, sadwara dan saptawara menggunakan mo $\delta 5,6$, dan 7. Artinya untuk menentukan hari ke- $x$ dengan $x=1$, 2, ..., 210 maka untuk pancawara digunakan mo 5 , untuk sadwara digunakan

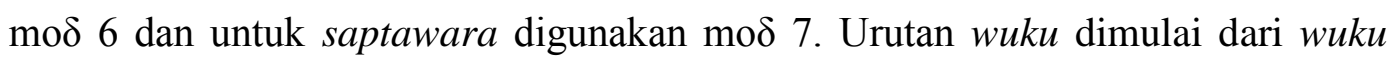
Sinta, Landep dan seterusnya hingga Watu Gunung, berganti setiap tujuh hari. Berikut ini aturan untuk menentukan nama hari pancawara, sadwara dan saptawara dan wuku.

\section{Nama Pancawara, Sadwara dan Saptawara}

Misalkan $x$ adalah nomor urut hari pada Pawukon Saka, maka nama hari masing-masing wewaran adalah $t$ pada tabel 3 yang ditentukan oleh aturan berikut: 


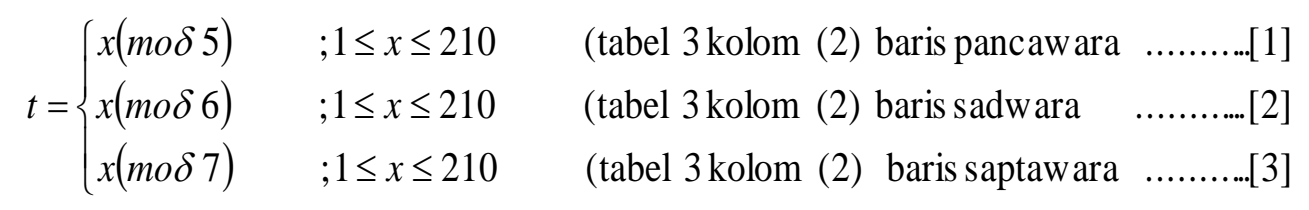

\section{Nama Wuku}

Misalkan $x$ adalah nomor urut hari pada Pawukon Saka, maka nama wuku adalah $w$ pada tabel 3 yang ditentukan oleh aturan

$$
w=\langle\langle x: 7\rangle\rangle \quad \text { (tabel } 3 \text { kolom }(2))
$$

Sebagai contoh nomor hari ke-100 akan jatuh pada

$$
\begin{array}{lll}
\text { Pancawara: } & 100=(5 \times 19)+5 ; & t=5: \text { Umanis } \\
\text { Sadwara: } & 100=(6 \times 16)+4 ; & t=4: \text { Paniruan } \\
\text { Saptawara: } & 100=(7 \times 14)+2 ; & t=2: \text { Soma/Senin } \\
\text { Wuku: } & w=\langle\langle 100: 7\rangle\rangle=15 & w=15: \text { Julung Pujut }
\end{array}
$$

Tabel 4 Nama hari ke-100 pada Pawukon Saka

\begin{tabular}{|c|c|c|c|c|}
\hline Hari ke & Pancawara & Sadwara & Saptawara & Wuku \\
\hline 100 & Umanis & Paniruan & Soma & Julung Pujut \\
\hline
\end{tabular}

Aturan-aturan di atas menjelaskan bahwa Pawukon Saka dibangun dengan aturan-aturan matematika (aritmatika), khususnya Matematika Jawa. Rumus [1], [2], dan [3] menjelaskan bahwa jumlah hari 210 dalam satu kali siklus Pawukon Saka merupakan hasil kali 5, 6 dan 7 yang merupakan jumlah hari pancawara, sadwara dan saptawara. Hasil dari seluruh aturan [1], [2], [3], dan [4] tersebut disajikan pada tabel 5 yang hanya menyajikan sebagian saja. Cara pembacaan kode angka dapat diambil contoh 0605 yang menyatakan anasir sadwara (06) dengan nomor urut $(05)=5$ yang dapat dilihat pada tabel 3 bahwa hari sadwara pada baris ke-5 adalah was. Secara lengkap 0505060607073030 berarti Umanis, Mawulu, Saniscara, Watugunung. 
Tabel 5 Pawukon Saka

\begin{tabular}{|c|c|c|c|c|c|c|c|c|}
\hline $\begin{array}{l}\text { Hari } \\
(x)\end{array}$ & \multicolumn{2}{|c|}{$\begin{array}{c}\text { Pancawara } \\
(05)\end{array}$} & \multicolumn{2}{|c|}{$\begin{array}{c}\text { Sadwara } \\
(06)\end{array}$} & \multicolumn{2}{|c|}{$\begin{array}{c}\text { Saptawara } \\
(07)\end{array}$} & \multicolumn{2}{|c|}{$\begin{array}{c}\text { Wuku } \\
\text { (30) }\end{array}$} \\
\hline 1 & Pahing & 0501 & Tunglai & 0601 & Raditya & 0701 & Sinta & 3001 \\
\hline 2 & Pon & 0502 & Hariyang & 0602 & Soma & 0702 & Sinta & 3001 \\
\hline 3 & Wagai & 0503 & Wurukung & 0603 & Anggara & 0703 & Sinta & 3001 \\
\hline 4 & Kaliwuan & 0504 & Paniruan & 0604 & Budha & 0704 & Sinta & 3001 \\
\hline 5 & Umanis & 0505 & Was & 0605 & Wrhaspati & 0705 & Sinta & 3001 \\
\hline 6 & Pahing & 0501 & Mawulu & 0606 & Sukra & 0706 & Sinta & 3001 \\
\hline 7 & Pon & 0502 & Tunglai & 0601 & Saniscara & 0707 & Sinta & 3001 \\
\hline 8 & Wagai & 0503 & Hariyang & 0602 & Raditya & 0701 & Landep & 3002 \\
\hline 9 & Kaliwuan & 0504 & Wurukung & 0603 & Soma & 0702 & Landep & 3002 \\
\hline 10 & Umanis & 0505 & Paniruan & 0604 & Anggara & 0703 & Landep & 3002 \\
\hline 65 & Umanis & 0505 & Was & 0605 & Soma & 0702 & Julung Sungsang & 3010 \\
\hline 66 & Pahing & 0501 & Mawulu & 0606 & Anggara & 0703 & Julung Sungsang & 3010 \\
\hline 67 & Pon & 0502 & Tunglai & 0601 & Budha & 0704 & Julung Sungsang & 3010 \\
\hline 68 & Wagai & 0503 & Hariyang & 0602 & Wrhaspati & 0705 & Julung Sungsang & 3010 \\
\hline 69 & Kaliwuan & 0504 & Wurukung & 0603 & Sukra & 0706 & Julung Sungsang & 3010 \\
\hline 70 & Umanis & 0505 & Paniruan & 0604 & Saniscara & 0707 & Julung Sungsang & 3010 \\
\hline 71 & Pahing & 0501 & Was & 0605 & Raditya & 0701 & Duniulan & 3011 \\
\hline 72 & Pon & 0502 & Mawulu & 0606 & Soma & 0702 & Dunulan & 3011 \\
\hline 73 & Wagai & 0503 & Tunglai & 0601 & Anggara & 0703 & Dunulan & 3011 \\
\hline 74 & Kaliwuan & 0504 & Hariyang & 0602 & Budha & 0704 & Dunulan & 3011 \\
\hline 99 & Kaliwuan & 0504 & Wurukung & 0603 & Raditya & 0701 & Julung Pujut & 3015 \\
\hline 100 & Umanis & 0505 & Paniruan & 0604 & Soma & 0702 & Julung Pujut & 3015 \\
\hline 101 & Pahing & 0501 & Was & 0605 & Anggara & 0703 & Julung Pujut & 3015 \\
\hline 102 & Pon & 0502 & Mawulu & 0606 & Budha & 0704 & Julung Pujut & 3015 \\
\hline 103 & Wagai & 0503 & Tunglai & 0601 & Wrhaspati & 0705 & Julung Pujut & 3015 \\
\hline 104 & Kaliwuan & 0504 & Hariyang & 0602 & Sukra & 0706 & Julung Pujut & 3015 \\
\hline 105 & Umanis & 0505 & Wurukung & 0603 & Saniscara & 0707 & Julung Pujut & 3015 \\
\hline 106 & Pahing & 0501 & Paniruann & 0604 & Raditya & 0701 & Pahang & 3016 \\
\hline 203 & Wagai & 0503 & Was & 0605 & Saniscara & 0707 & Dukut & 3029 \\
\hline 204 & Kaliwuan & 0504 & Mawulu & 0606 & Raditya & 0701 & Watugunung & 3030 \\
\hline 205 & Umanis & 0505 & Tunglai & 0601 & Soma & 0702 & Watugunung & 3030 \\
\hline 206 & Pahing & 0501 & Hariyang & 0602 & Anggara & 0703 & Watugunung & 3030 \\
\hline 207 & Pon & 0502 & Wurukung & 0603 & Budha & 0704 & Watugunung & 3030 \\
\hline 208 & Wagai & 0503 & Paniruan & 0604 & Wraspati & 0705 & Watugunung & 3030 \\
\hline 209 & Kaliwuan & 0504 & Was & 0605 & Sukra & 0706 & Watugunung & 3030 \\
\hline 210 & Umanis & 0505 & Mawulu & 0606 & Saniscara & 0707 & Watugunung & 3030 \\
\hline
\end{tabular}

\section{Uji Prasasti}

Tabel 2 mencatatkan data-data prasasti terkait dengan Pawukon Saka. Data-data tersebut akan dikonfirmasi dengan tabel 5 sehingga dapat diidentifikasi nomor urut Pawukon Saka dari data-data prasasti tersebut. Hasilnya diberikan 
pada tabel 6. Pada tabel 6, nama-nama prasasti dihilangkan dan dicantumkan nomor urutnya saja. Kolom paling kanan tabel 6 adalah nomor urut hari dalam Pawukon Saka (dari 1 - 210).

Tabel 6 Identifikasi data prasasti berdasarkan Pawukon Saka yang telah dibuat

\begin{tabular}{|c|c|c|c|c|c|c|c|}
\hline \multirow{2}{*}{$\begin{array}{l}\mathbf{N} \\
\mathbf{0 .}\end{array}$} & \multicolumn{3}{|c|}{ Wara pada Prasasti } & \multirow{2}{*}{$\begin{array}{c}\text { Wuku pada } \\
\text { Prasasti }\end{array}$} & \multirow{2}{*}{$\begin{array}{l}\text { Wuku yang } \\
\text { seharusnya }\end{array}$} & \multirow{2}{*}{$\begin{array}{l}\text { Tahun } \\
\text { (Saka) }\end{array}$} & \multirow{2}{*}{$\begin{array}{c}\text { No. } \\
\text { Uru } \\
\mathbf{t}\end{array}$} \\
\hline & Pancawara & Sadwara & Saptawara & & & & \\
\hline \multicolumn{8}{|c|}{ Jawa Tengah, Jawa Timur dan Yogyakarta } \\
\hline 1 & - & - & soma & - & $?$ & $654 \mathrm{~S}$ & $?$ \\
\hline 2 & pon & was & sukra & - & prangbakat & $714 \mathrm{~S}$ & 167 \\
\hline 3 & wagai & wurukung & wrehaspati & - & taulu & $778 \mathrm{~S}$ & 33 \\
\hline 4 & pahim & vurukum & sukra & - & pahang & $779 \mathrm{~S}$ & 111 \\
\hline 5 & $\begin{array}{c}\text { pon } \\
\text { kaliwuan }\end{array}$ & $\begin{array}{l}\text { wurukung } \\
\text { paniron }\end{array}$ & $\begin{array}{l}\text { soma } \\
\text { buda }\end{array}$ & - & $\begin{array}{c}u g u \\
\text { sinta }\end{array}$ & $782 \mathrm{~S}$ & $\begin{array}{c}177 \\
4\end{array}$ \\
\hline 6 & kaliwuan & wurukun் & soma & - & landep & $788 \mathrm{~S}$ & 9 \\
\hline 7 & pon & tunlai & soma & - & gumbreg & $797 \mathrm{~S}$ & 37 \\
\hline 8 & umanis & paniron & sukra & - & menail & $800 \mathrm{~S}$ & 160 \\
\hline 9 & wagai & tunglai & sukra & & landep & $803 \mathrm{~S}$ & 13 \\
\hline 10 & pon & tumlai & soma & - & gumbreg & $812 \mathrm{~S}$ & 37 \\
\hline 11 & wagai & was & wrhaspati & - & bala & $828 \mathrm{~S}$ & 173 \\
\hline 12 & umanis & tunglai & saniscara & - & bala & $829 \mathrm{~S}$ & 175 \\
\hline 13 & umanis & wurukum & soma & - & medangkungan & $905 \mathrm{~S}$ & 135 \\
\hline 14 & wagai & was & amgara & mahatal & mahatal & $1188 \mathrm{~S}$ & 143 \\
\hline 15 & umanis & hariyang & saniscara & maḍankañan & maḍankañan & $1216 \mathrm{~S}$ & 140 \\
\hline 16 & kaliwuan & tumilai & caniscara & kuninian & $\begin{array}{c}\text { Wariganing } \\
\text { wariga }\end{array}$ & $1218 \mathrm{~S}$ & 49 \\
\hline 17 & umanis & tunlai & à்gara & krulwut & krulwut & $1245 \mathrm{~S}$ & 115 \\
\hline 18 & pon & hariyang & buda & tolu & tolu & $1273 \mathrm{~S}$ & 32 \\
\hline 19 & manis & mawulu & sukra & lä́kir & lankir & $1395 \mathrm{~S}$ & 90 \\
\hline \multicolumn{8}{|c|}{ Bali } \\
\hline 20 & wage & $\begin{array}{c}\text { untuk } \\
\text { urukung? }\end{array}$ & wrhaspati & gumrg & taulu & $993 \mathrm{~S}$ & 33 \\
\hline \multicolumn{8}{|c|}{ Jawa Barat } \\
\hline 21 & pon & haryang & wrehaspati & - & uye & - & 152 \\
\hline 22 & kaliwuan & wurukung & amgara & - & tambir & $794 \mathrm{~S}$ & 129 \\
\hline 23 & kaliwuan & hariyang & radite & tambir & madangkungan & $952 \mathrm{~S}$ & 134 \\
\hline \multicolumn{8}{|c|}{ Sumatera Barat } \\
\hline 24 & wage & mawulu & wrhaspati & madangkungan & madangkungan & $1208 \mathrm{~S}$ & 138 \\
\hline
\end{tabular}

Dari hasil uji prasasti di atas, dapat ditentukan nama $w u k u$ dan nomor urut hari Pawukon Saka, apabila tiga buah wewaran diketahui. Prasasti Sukamerta (no. 
16) keliru dalam menuliskan nama wuku, seharusnya wariganing wariga dipahatkan kuninan. Prasasti Pandak Badung (no. 20) keliru dalam menuliskan urukung dan nama wuku yang seharusnya taulu. Prasasti Cicatih (no. 23) juga keliru dalam menuliskan nama wuku, yang seharusnya medangkungan. Berikut adalah tiga cara/metode untuk menguji kebenaran nama wuku pada prasasti.

\section{Penyelesaian Pertama: Metode Tabulasi}

Tiga buah prasasti (Sukamerta, Pandak Badung dan Cicatih) menuliskan nama wuku yang keliru (tabel 7). Wuku apakah yang seharusnya? Tidak sulit mencarinya sebab tabel Pawukon Saka sudah dibuat dengan aturan [1], [2], [3] dan [4].

Tabel 7 Kekeliruan nama $w u k u$ pada prasasti

\begin{tabular}{|c|c|c|c|c|c|c|c|}
\hline \multirow[t]{2}{*}{ No. } & \multicolumn{3}{|c|}{ Wara pada Prasasti } & \multirow{2}{*}{$\begin{array}{c}\text { Wuku pada } \\
\text { Prasasti }\end{array}$} & \multirow{2}{*}{$\begin{array}{c}\text { Wuku } \\
\text { yang benar }\end{array}$} & \multirow{2}{*}{$\begin{array}{l}\text { Tahun } \\
\text { (Saka) }\end{array}$} & \multirow{2}{*}{$\begin{array}{l}\text { No. } \\
\text { Urut }\end{array}$} \\
\hline & Pancawara & Sadwara & Saptawara & & & & \\
\hline 16 & $\begin{array}{l}\text { kaliwuan } \\
0504\end{array}$ & $\begin{array}{c}\text { tumilai } \\
0601\end{array}$ & $\begin{array}{c}\text { caniscara } \\
0707\end{array}$ & kuninan & $\begin{array}{c}\text { Wariganing } \\
\text { wariga }\end{array}$ & $1218 \mathrm{~S}$ & 49 \\
\hline 20 & $\begin{array}{l}\text { wage } \\
0503\end{array}$ & $\begin{array}{c}\text { urukung } \\
0603\end{array}$ & $\begin{array}{c}\text { wrhaspati } \\
0705\end{array}$ & gumrg & taulu & $993 \mathrm{~S}$ & 33 \\
\hline 23 & $\begin{array}{c}\text { kaliwuan } \\
0504\end{array}$ & $\begin{array}{c}\text { hariyang } \\
0602\end{array}$ & $\begin{array}{c}\text { radite } \\
0701\end{array}$ & tambir & madangkungan & $952 \mathrm{~S}$ & 134 \\
\hline
\end{tabular}

Masalah pertama, kaliwuan, tumlai, caniscara menurut Prasasti Sukamerta bertepatan dengan wuku Kuningan. Apakah hal ini benar? Untuk menjawabnya, gunakan kode untuk kaliwuan, tumlai, caniscara seperti tampak pada tabel 9 nomor 16. Kaliwuan adalah hari pancawara ke-4 sehingga dikodekan dengan 0504 yang artinya 05 (pancawara) dan 04 (ke-4).

Misalkan $x$ adalah nomor urut hari pawukon sehingga model matematika untuk pancawara kaliwuan yaitu $x(\operatorname{mo} \delta 5)=4$. Nilai $x$ bisa $4,9,14,19, \ldots$ Model matematika untuk tumlai adalah $x(\operatorname{mo} \delta 6)=1$ dan untuk saniscara adalah $x(\operatorname{mo} \delta 7)=7$. Ketiga model tersebut membentuk masalah berapa nilai $x$ yang memenuhi $x(\operatorname{mo} \delta 5)=4, x(\operatorname{mo} \delta 6)=1$, dan $x(\operatorname{mo} \delta 7)=7$ ? 
Manusia Jawa telah menyiapkan tabel Pawukon Saka sehingga solusinya dapat langsung dilacak dari tabel tersebut. Berdasarkan tabel 5, kode angka 0501 akan ditulis 1 (digit terakhir). Demikian juga untuk yang lain sehingga tabel 5 akan menjadi tabel 8 dalam susunan mendatar. Untuk pancawara kaliwuan, $x(\operatorname{mo} \delta 5)=4$ berarti mencari angka 4 pada baris tersebut. Demikian juga untuk lainnya sehingga diperoleh kombinasi 4,1 dan 7 pada nomot urut hari $x=49$.

Tabel 8 Pawukon Saka dalam angka

\begin{tabular}{|c|c|c|c|c|c|c|c|c|c|c|c|c|c|c|c|}
\hline $\begin{array}{l}\text { No Urut Hari } \\
x\end{array}$ & 1 & 2 & 3 & 4 & 5 & 6 & 7 & 8 & $\cdots$ & 47 & 48 & 49 & 50 & .... & 210 \\
\hline $\begin{array}{c}\text { No dan Nama } \\
\qquad W u k u\end{array}$ & \multicolumn{7}{|c|}{ 1. Sinta } & 2. & $\cdots \cdots$ & \multicolumn{3}{|c|}{$\begin{array}{c}\text { 7. Wariganing } \\
\text { Wariga }\end{array}$} & 8. & ....... & 30. \\
\hline $\begin{array}{c}\text { pancawara } \\
\text { kaliwuan } \\
x(\text { mo } \delta 5)=4\end{array}$ & 1 & 2 & 3 & 4 & 5 & 1 & 2 & 3 & $\ldots$ & 2 & 3 & 4 & 5 & $\cdots$ & 5 \\
\hline $\begin{array}{c}\text { sadwara } \\
\text { tumlai } \\
x(\operatorname{mo} \delta 6)=1\end{array}$ & 1 & 2 & 3 & 4 & 5 & 6 & 1 & 2 & $\ldots$ & 5 & 6 & 1 & 2 & $\ldots$ & 6 \\
\hline $\begin{array}{c}\text { saptawara } \\
\text { saniscara } \\
x(\operatorname{mo} \delta 7)=7\end{array}$ & 1 & 2 & 3 & 4 & 5 & 6 & 7 & 1 & $\cdots$ & 5 & 6 & 7 & 1 & $\ldots$ & 7 \\
\hline
\end{tabular}

\section{Penyelesaian Kedua: Metode Modulo Jawa}

Cara lain dapat dirunut dari tabel berikut yang dihitung sampai angka tertinggi pada pawukon yaitu 210. Prosesnya diberikan pada tabel 9 dan hasil yang diperoleh adalah $x=49$.

Tabel 9 Nilai $x$ pada masalah Prasasti Sukamerta

\begin{tabular}{|c|c|c|}
\hline $\begin{array}{c}\text { Model } \\
\text { Matematika }\end{array}$ & $\begin{array}{c}\text { Nilai } x \text { yang mungkin } \\
1 \leq x \leq 210\end{array}$ & Jawaban \\
\hline $\begin{array}{c}\text { kaliwuan } \\
x(\operatorname{mo} \delta 5)=4\end{array}$ & $\begin{array}{l}4,9,14,19,24,29,34,39,44,49,54,59,64,69,74, \\
79,84,89,94,99,104,109,114,119,124,129,134, \\
139,144,149,154,159,164,169,174,179,184,189, \\
194,199,204,209 .\end{array}$ & 49 \\
\hline $\begin{array}{c}\text { tumlai } \\
x(\operatorname{mo} \delta 6)=1\end{array}$ & $\begin{array}{l}1,7,13,19,25,31,37,43,49,55,61,67,73,79,85, \\
91,97,103,109,115,121,127,133,139,145,151, \\
157,163,169,175,181,187,193,199,205 .\end{array}$ & \\
\hline
\end{tabular}




\begin{tabular}{|c|l|l|} 
saniscara & $7,14,21,28,35,42,49,56,63,70,77,84,91,98$, & \\
$x(\operatorname{mo} \delta 7)=7$ & $\begin{array}{l}105,112,119,126,133,140,147,154,161,168,175, \\
182,189,196,203,210 .\end{array}$ & \\
\hline
\end{tabular}

Dari tabel 8 dan 9 diperoleh nomor urut hari Pawukon Saka adalah $x=49$. Umur setiap wuku adalah tujuh hari sehingga hari ke-49 merupakan hari ketujuh untuk wuku ketujuh $(7 \times 7=49)$ yang jatuh pada wuku wariganing wariga (bukan kuningan).

\section{Penyelesaian Ketiga: The Chinese Remainder Problem}

Dalam siklus 210 hari, kombinasi tiga nama hari dalam pancawara, sadwara dan saptawara selalu muncul sehingga kekeliruan yang mungkin adalah pada penyebutan nama $w u k u$. Kekeliruan penyebutan nama wuku memunculkan pertanyaan yang merupakan masalah mtematika. Namun, jika dicermati lebih lanjut, permasalahan menentukan wuku yang benar merupakan masalah matematika yang dapat diselesaikan dengan metode dalam The Chinese Remainder Problem (CRT).

Sun Tzu (abad ke-4 M) memberikan metode untuk memecahkan masalah yang saat ini dikenal dengan nama The Chinese Remainder Theorem/Problem. Kekeliruan penulisan nama wuku pada prasasti yang memuat Pawukon Saka merupakan masalah yang sejenis dengan CRT. Meskipun CRT bekerja pada modulo matematika, tetapi dapat diterapkan pada Modulo Jawa.

Kembali pada masalah menentukan $x$ yang memenuhi $x(\operatorname{mo} \delta 5)=4$, $x(\operatorname{mo} \delta 6)=1$, dan $x(\operatorname{mo} \delta 7)=7$. Masalah ini identik dengan menentukan $x$ yang memenuhi $x \equiv 4(\operatorname{mo} \delta 5) \equiv 1(\operatorname{mo} \delta 6) \equiv 7(\operatorname{mo} \delta 7)$. Pitts $\quad(2005)$ memberikan solusi sebagai berikut:

Sisa

$$
a_{1}=4 \quad a_{2}=1 \quad a_{3}=7
$$

Modulo

$$
m_{1}=5 \quad m_{2}=6 \quad m_{3}=7
$$

Hasil kali modulo

$$
\begin{aligned}
& m=5 \cdot 6 \cdot 7=210 \\
& z_{1}=\frac{m}{m_{1}}=42 \quad z_{2}=\frac{m}{m_{2}}=35 \quad z_{3}=\frac{m}{m_{3}}=30
\end{aligned}
$$




$$
\begin{array}{lllll}
z_{i} \cdot y_{i} \equiv 1\left(\operatorname{mo} \delta m_{i}\right) & & & & \\
42 y_{1} \equiv 1(\operatorname{mo} \delta 5) & \rightarrow & 42 y_{1}+5 t=1 & \rightarrow & y_{1}=3 \\
35 y_{2} \equiv 1(\operatorname{mo} \delta 6) & \rightarrow & 35 y_{2}+6 t=1 & \rightarrow & y_{2}=5 \\
30 y_{3} \equiv 1(\operatorname{mo} \delta 7) & \rightarrow & 30 y_{2}+7 t=1 & \rightarrow & y_{3}=4
\end{array}
$$

Solusi $x=a_{1} y_{1} z_{1}+a_{2} y_{2} z_{2}+a_{3} y_{3} z_{3}(\operatorname{mo} \delta m)$

$$
x=4 \cdot 3 \cdot 42+1 \cdot 5 \cdot 35+7 \cdot 4 \cdot 30(\operatorname{mo} \delta 210)=1519(\operatorname{mo} \delta 210)=49
$$

Jawaban $x=49$ menyatakan hari ke-49 pada Pawukon Saka. Untuk menentukan nama wuku digunakan fungsi tangga naik (definisi 1) dengan membagi $x$ oleh 7 (setiap wuku 7 hari): $\langle\langle x: 7\rangle\rangle=7$. Wuku dengan nomor urut 7 adalah wariganing wariga (bukan kuningan).

Masalah pada prasasti dengan nomor 20 dan 23 pada tabel 6 serupa dengan masalah pada prasasti nomor 16 yang telah dipecahkan. Solusinya ditabelkan pada tabel 10

Tabel 10 Solusi dengan The Chinese Remainder Problem

\begin{tabular}{|l|c|c|c|c|}
\hline No & Masalah & Masalah yang identik & $x$ & $\begin{array}{c}\text { Nomor Wuku }(w) \\
\text { Nama Wuku }\end{array}$ \\
\hline 16 & $\begin{array}{l}x(\operatorname{mo} \delta 5)=4 \\
x(\operatorname{mo} \delta 6)=1 \\
x(\operatorname{mo} \delta 7)=7\end{array}$ & $x \equiv 4(\operatorname{mo} \delta 5) \equiv 1(\operatorname{mo} \delta 6) \equiv 7(\operatorname{mo} \delta 7)$ & 49 & $\begin{array}{c}\langle\langle 49: 7\rangle\rangle=\langle\langle 7\rangle\rangle=7 \\
\text { Wariganing wariga }\end{array}$ \\
\hline 20 & $\begin{array}{l}x(\operatorname{mo} \delta 5)=3 \\
x(\operatorname{mo} \delta 6)=3 \\
x(\operatorname{mo} \delta 7)=5\end{array}$ & $x \equiv 3(\operatorname{mo} \delta 5) \equiv 3(\operatorname{mo} \delta 6) \equiv 5(\operatorname{mo} \delta 7)$ & 33 & $\langle\langle 33: 7\rangle\rangle=\langle\langle 4,71\rangle\rangle=5$ \\
\hline 23 & $x(\operatorname{mo} \delta 5)=4$ & $x \equiv 4(\operatorname{mo} \delta 5) \equiv 2(\operatorname{mo} \delta 6) \equiv 1(\operatorname{mo} \delta 7)$ & 134 & Taulu \\
& $x(\operatorname{mo} \delta 6)=2$ & & & Medangkungan \\
\hline & & & \\
\hline
\end{tabular}

\section{KESIMPULAN}

Penggunaan Pawukon Saka telah ada sejak Mataram Kuno hingga runtuhnya Majapahit dan masih diteruskan hingga masa Sultan Agung di Mataram 
Islam. Jumlah 210 hari dalam Pawukon Saka berasal dari siklus bersama 5, 6, dan 7 hari dari tiga jenis wewaran. Jenis wewaran yang pertama kali digunakan adalah saptawara (654 Saka), disusul dua jenis wewaran sekaligus (pancawara dan sadwara, 714 Saka). Penggunaan nama wuku yang menandakan Pawukon baru digunakan pada tahun 952 Saka terpahat di Prasasti Cicatih. Fakta ini menjelaskan bahwa Pawukon telah digunakan pada tahun 1030 Masehi.

Pawukon Saka yang dibangun oleh pancawara, sadwara, saptawara dan 30 buah wuku diciptakan dengan aritmatika yaitu modulo 5, 6 dan 7 sehingga Pawukon Saka dapat disebut sebagai mathematical calendar. Hari pertama Pawukon Saka adalah Radite-Paing, Tungle, wuku Sinta.

Aturan untuk menentukan nama hari suatu wewaran (pancawara, sadwara, dan saptawara) menggunakan aritmatika berdasarkan Modulo Jawa pada nomor urut hari Pawukon. Dengan menggunakan aturan [1], [2], [3], dan [4] dapat disusun tabel Pawukon Jawa yang salah satu kegunaannya mengecek kebenaran nama wuku (uji wuku).

Metode yang digunakan untuk menyelesaikan The CRP Problem dapat dipakai untuk menentukan nomor urut hari Pawukon Saka, apabila tiga nama hari wewaran diketahui. Selanjutnya, dengan menggunakan fungsi tangga naik dan fungsi tangga maka nama wuku dapat diketahui.

\section{DAFTAR PUSTAKA}

Andreanto, R. Waktu Terbaik Penurunan Keputusan Raja: Analisis Berdasarkan Unsur Penanggalan pada Prasasti Jawa Kuno Abad ke-9 dan ke-10 Masehi. Skripsi pada Program Studi Arkeologi, Fakultas Ilmu Budaya, Universitas Indonesia, 2008

Pitts, J. T., Chinese Reminder Theorem, www. http://www.math.tamu.edu/ jon.pitts/courses/2005c/470/supplements/chin ese.pdf, diakses pada 24 Mei 2014.

Prabowo, A. dan Sidi, P., Tarikh Jawa: Kalender Lunar Berbasis Matematika. Jurnal Edumat PPPPTK, Vo. 3, No. 6, h. 395-410, Yogyakarta, 2012. 
Prabowo, A. dan Sidi, P., Permulaan Matematika dalam Peradaban BangsaBangsa: Kontribusi Budaya Jawa dalam Matematika, Penerbit Universitas Jenderal Soedirman, Purwokerto, 2014.

Prabowo, A., The Pakubuwono Code, Phoenix Publishing, Jakarta, 2014. 